\title{
Entrepreneurship Uptake A Solution to Unemployment Challenges in Developing Countries: A Study of Nigeria
}

\author{
Article by Babalola Samuel Alabi ${ }^{1}$, Gbemisola Sarah Idris ${ }^{2}$ \\ ${ }^{1}$ Faculty and Department, Texila American University/ MGT \\ ${ }^{2}$ Ekiti State University Ado Ekiti / MGT \\ Email:alabibabs2000@yahoo.com ${ }^{1}$,gbemiidris@gmail.com ${ }^{2}$
}

\begin{abstract}
The increasing rate of unemployment across states of most developing countries is gradually becoming too much to handle for most of their government. It is however evidence that if unemployment rate is allowed to continually grow, couple with mass retrenchment or sack of staff and increasing the population, then the nation is heading towards a shutdown. This study examines entrepreneurship a Solution to unemployment challenges in developing countries: a study of Nigeria. The study adopted descriptive design in the conduction of this study among entrepreneurs spread across six states within the southwestern geopolitical zone in Nigeria. Data were collected from primary sources through the administration of questionnaire to 323 respondents selected using the Area Sampling Technique; and they were analyzed using descriptive statistics. The result of the study revealed that, Factors militating against adoption of entrepreneurship in Nigeria include government policy, Availability and sources of fund, Inadequate knowledge of areas to explore and Family background. Other findings revealed that; entrepreneurship would influence unemployment challenges. Since it helps to improve individual financial capacity, standard of living of the people, faced out Unemployment, turn youths away from all forms of violence and help reduce the poverty level in the country. More findings revealed that, in other to make entrepreneurship attractive to young people, entrepreneurship studies in tertiary institutions should be reviewed and should be practical oriented, government at all level should organize entrepreneurship workshop and seminar in place of worship, communities and other areas of concentration to include other youths, government should endavour to make soft loan available for entrepreneurs to enable them improve on their productivity, entrepreneurs should be assisted financially (subsidizing cost) to attend international conferences to help and all media platforms should be engage in the campaign for adoption of entrepreneurship using every Nigeria languages.
\end{abstract}

Keyword: Entrepreneurship, Unemployment, Developing countries

\section{Introduction}

The increasing rate of unemployment across states of most developing countries is gradually becoming too much to handle for most of their government. The most recent data released by Nigeria Bureau of Statistics shows that, unemployment index is slated for above 20 million of the total population. Unemployment is gradually becoming a lifestyle among the youth, whereby, after service year (National Youth Corp Service), for a period of one year, they already aware that, they have to wait in search for jobs. This has contributed to the recent questions spreading among the youths, which states that, "what is the benefit of going to a university to waste some years, when those that didn't border going already are living large and doing great". This by no means is relegating the pride of education in this part of the world. Aside the fact that Nigeria tertiary institutions produce a lot of graduates every year, most companies and industries like multinational, banks also retrench their staff in numbers. This however is consequential in the continual increase of insecurity, rate of poverty, school dropout among others. This was reiterated in the work of Bokhari (2013), who opines that, one of the most pressing challenges facing government and policy makers is unemployment. He noted further that, the underlying problem is that an 
increasing number of youth graduates from high schools, colleges and universities are seeking opportunities in the labour market every year. This problem is mostly peculiar to developing countries, where youths can no longer depend on the public and private sector in providing job opportunities. Therefore, the need to turn to entrepreneurship as an alternative means is now a necessity.

Entrepreneurial development has been conceived by successive government as a programme of activities to enhance the knowledge, skill, behaviour and attitudes of individual and groups to assume the role of entrepreneurs. Taking this into account they have put in place confidence for building successful programmes in different parts of Nigeria (Owualah, 1999 cited in Osemeke, 2012). Entrepreneurship involves an application of energy and passion towards the creation of an enterprise and these includes: team work, creative skill to marshal needed resources, fundamental skill of building, solid business plan, and finally, the vision to recognize opportunity where others see chaos, contradiction, and confusion (Arenius, 2004). However, certain factors have been noted to be of high importance to entrepreneurial development in the society. A paper presented at a workshop on entrepreneurship and innovation by Osibanjo (2006) in university of Ibadan which was titled 'Concept of Entrepreneurship', shows that, entrepreneurial programme focused on development of youth through passion and multiple skills. The implication of this is that, entrepreneurship is aim at reducing the risk associated with its practices and therefore guide the enterprise successfully through it initial stage to the maturity stage. In concordance with the above, Brown (2000) opined that, entrepreneurial programmes are designed to communicate and inculcate competencies, skills and values needed for recognize business opportunity, organize and start new business venture mainly among the youth

Furthermore, the pitiable state of joblessness in Nigeria, led the federal government under the regime of Olusegun Obasanjo in 2006, to mandate entrepreneurial studies to be offered by tertiary institutions undergraduates regardless of discipline, so as to reduce the rate of unemployment in the country. This idea was borne out of the fact that, entrepreneurial studies have the capacity to equip students with skills that will aid them in becoming a competent entrepreneur and not job seekers. It also due to the clear evidence that, available space for jobs in Nigeria a both the public and the private sectors cannot accommodate the graduates being produced every year, let alone, the left over. More so, previous effort by the government to curtail unemployment have saw the establishment of various initiative like the National Poverty Eradication Programme (NAPEP) and the establishment of Small and Medium Enterprises Development Agency of Nigeria (SMEDAN) have been introduced to assist the fresh graduates (Okojie, 2008; Osibanjo, 2006). However, the rates of unemployment in the society remain unchanged. This maybe probably due to the assertion of Oluwole (2003), who observed that, the facts remain that most initiatives in Nigeria addressed only the output end of capacity development solving problem. In his study, he procured that, in addressing the input end a complementary approach is required.

According to Bokhari (2013) one of the motivations for studying the relationship between entrepreneurship and unemployment is the policy interest about promoting entrepreneurship as a way of reducing unemployment. Entrepreneurship and self-employment among youth, and the creation of small and medium enterprises is suggested as one of the major sources of employment opportunities for young people. However, entrepreneurship dampens unemployment, unemployment spurs entrepreneurship (Bokhari, 2013 citing Plehn-Dujowich, 2012). On one hand, higher rates of entrepreneurial activities may reduce unemployment rates through self-employment and the consequent creation of new jobs.

Previous work by Audretsch, Carree and Thurik (2004), finds that there is a dynamic inter-relationship between self-employment and unemployment rates. On the one hand, unemployment rates may stimulate start-up activity of self-employed. On the other hand, higher rate of self-employment may indicate increased entrepreneurial activity, reducing unemployment in subsequent period. Also, According to Yakubu (2000), gone are the days, when Nigeria used to be a guarantee for any type of jobs. It has now become a story that in the days of old, all categories of graduates from the university, secondary and even primary schools had the opportunity to have access to any type of job among a pool that was begging for 
selection. More so, Oluwole (2003) also reiterated that, if Nigerians are to perform optimally their intervention role in salvaging the never-do-well economy of the nation through entrepreneurship activities, then it becomes necessary that there should be a special fund arrangement such as risk fund or venture capital. It is against this backdrop this study examines, entrepreneurship a Solution to unemployment challenges in developing countries: a study of Nigeria.

\section{Methodology}

\section{Research design}

The study used descriptive design to obtain information about entrepreneurship a solution to unemployment challenges in developing countries. Data were collected from primary sources through the use of questionnaire distributed to the target respondents randomly. The questionnaire was designed to apply to a heterogeneous population, where the respondents come from the general open public with no bias for gender, education, background and profession. This was done because different level of society has different expectations and needs, therefore the idea of choosing respondents from different background will certainly generate more reliable outcome.

\section{Population, sample size and sampling technique}

The target population of this study comprise of entrepreneurs in South Western part of Nigeria, who are up to 18 years. The state involved include; Lagos, Ogun, Oyo, Osun, Ondo and Ekiti states. In order for the study to capture a good representation and produce good outcome, the collation of data was distributed over a large population. Considering the complexity of the nature of the population, the sample size of the study was determined using Kish formula at $30 \%$ sample size.

$\mathrm{N}=\frac{\mathrm{Z}^{2} \mathrm{Pq}}{\mathrm{d}^{2}}$

where $n=$ desired sample size

$\mathrm{p}=$ proportion of the population that possessed the characteristics $=0.30$

$\mathrm{Z}=$ level of confidence at 1.96

$\mathrm{q}=1-\mathrm{p}=1-0.30=0.70$

$\mathrm{d}=$ level of possession $=0.05$

these implies

$(1.96)^{2}(0.30)(0.70)=322.6$

$(0.05)^{2}$

Approximately 323.

Since the researcher was dealing with human being, there was tendency for some of them not to return the instrument. It is therefore imperative on the researcher to determine the attrition. It was calculated then-

Attrition rate of $10 \%$

$=\underline{\text { Initial sample rate } \mathrm{x} \text { attrition rate (10) }}$

Attrition rate (10) - 1

$=\underline{323 \times 10}=\underline{3230}=359.2$

$10-1 \quad 9$

Approximately 359 .

$359-323=36$. Therefore, the attrition rate of $10 \%=36$. The total sample size $=359$.

Furthermore, due to the heterogeneous nature of respondents, the study adopted the Area Sampling Technique which is a form of cluster sampling that focus on respondents' specialization. It therefore indicates that the areas where entrepreneurs are likely to be clustered in will be used as points of contacts; these areas include; conferences, workshop and various seminars. This sampling technique was adopted because it was not easy to obtain records. 
DOI: 10.21522/TIJMG.2015.SE.19.01.Art009

ISSN: $2520-310 \mathrm{X}$

\section{Data collection}

The data collection took place in the six states of the study area (Lagos, Ogun, Oyo, Osun, Ondo and Ekiti) in Nigeria. Respondents were approached in their various residence and offices for permission to be involved in the study. Those who accepted to participate in the study were presented with a copy of the instrument (questionnaire) to complete. The objective of the study was explained to them before the completion of the instrument. Data collection was done face to face by the researchers and two research assistants that have been trained by the researchers on how to go about the data collection.

\section{Data analysis technique}

Data obtained from the field were edited, sorted and processed into excel speed sheet before transfer into SPSS edition 22. Data was analysed using descriptive statistics. These include mean, standard deviation, minimum and maximum values respectively.

\section{Results}

\section{Demographic characteristics}

Table 1 below presents Frequency Distribution of respondents by Demographic Characteristics. Results on Sex of respondents revealed that, $67.5 \%$ were male, while $32.5 \%$ were female. Results on academic attainment of respondents revealed that, 56.0\% had secondary education, $24 \%$ attained their first degrees while $20 \%$ had their post graduates. Results on Religion of respondents revealed that, $78.9 \%$ were Christians, while $21.1 \%$ were Muslims.

\section{Factors militating against adoption of entrepreneurship in nigeria}

Table 2 above present descriptive statistics showing factors militating against adoption of entrepreneurship in Nigeria. result revealed that, government policy [mean $=4.19$ ]; Availability and sources of fund [mean= 3.80], Inadequate knowledge of areas to explore [mean= 3.30] and Family background [mean $=3.62$ ] are all factors that militating against adoption of entrepreneurship in Nigeria. however Individual career choice [mean $=2.88$ does not seem to pose much influence on entrepreneurship uptake.

\section{Entrepreneurship a solution to unemployment challenges in nigeria}

Table 3 above present descriptive statistics showing the influence of entrepreneurship on unemployment challenges. Result revealed that, Entrepreneurship may help to improve individual financial capacity [mean= 3.35]; The standard of living of the people can be improved through adoption of entrepreneurship as career [mean= 3.19], Unemployment will gradually fade out at increasing entrepreneurship uptake [mean=3.20] Entrepreneurship uptake could turn youths away from all forms of violence[mean= 3.30] and Entrepreneurship uptake will help reduce the poverty level in the country [mean=3.62]. This implies that, entrepreneurship influences unemployment challenges.

\section{What could be done to make young people adopt entrepreneurship in nigeria}

Table 4 above present descriptive statistics showing what could be done to make young people adopt entrepreneurship in Nigeria. Result revealed that, entrepreneurship studies in tertiary institutions should be reviewed and should be practical oriented [mean= 3.88]; Government at all level should organize entrepreneurship workshop and seminar in place of worship, communities and other areas of concentration to include other youths [mean= 3.35]; Government should endavour to make soft loan available for entrepreneurs to enable them improve their productivity [mean=3.19]; Entrepreneurs should be assisted financially to attend international conferences to help [mean= 3.20]; All media platforms should be engage in the campaign for adoption of entrepreneurship using ever Nigeria languages [mean= 3.30] all constitute what could be done to make entrepreneurship attractive to the unemployed. 


\section{Discussion}

Findings in this study revealed that, Factors militating against adoption of entrepreneurship in Nigeria include government policy, Availability and sources of fund, Inadequate knowledge of areas to explore and Family background. This implies that, in other increase the uptake of entrepreneurship among the youth, government need to be mindful of various policies that may scare youths from becoming entrepreneurs. This finding agrees with the study of Bokhari (2013), who opines that, one of the motivations for studying the relationship between entrepreneurship and unemployment is the policy interest about promoting entrepreneurship as a way of reducing unemployment.

More findings revealed that; entrepreneurship would influence unemployment challenges. Since it helps to improve individual financial capacity, standard of living of the people, faced out Unemployment, turn youths away from all forms of violence and help reduce the poverty level in the country. The plausible reason to this is that, entrepreneurship is capable of enriching an individual to the extent that, he can cater for his immediate family and other around him. This is in line with the finding of Ediagbonya (2013) found in their study of 237 graduates in the U.S. that business graduates generally perceived business ownership in a positive light.

Furthermore findings revealed that, in other to make entrepreneurship attractive to young people, entrepreneurship studies in tertiary institutions should be reviewed and should be practical oriented, government at all level should organize entrepreneurship workshop and seminar in place of worship, communities and other areas of concentration to include other youths, government should endavour to make soft loan available for entrepreneurs to enable them improve on their productivity, entrepreneurs should be assisted financially (subsidizing cost) to attend international conferences to help and all media platforms should be engage in the campaign for adoption of entrepreneurship using every Nigeria languages

\section{Conclusion}

In this $21^{\text {st }}$ century, the chances of getting a white-collar job after graduation is very slim, especially in developing countries. Aside the fact that, advances in technology has continued to create replacements for human in industries, the geometrically increasing population growth is a call for concern. Consequently, educational sector yields a large number of graduates from different higher institutions annually and there is a continual deficit of supply for job as against he demands. It is however quite unfortunate that, these graduates only stroll in streets looking for job opportunities which may never come in a country like Nigeria that is very rich in every resource sufficient for creation of jobs. Some of these youths on the long run become nuisance and political thugs. Yet the unemployed deficit continues to increase each day.

This study has shown that, entrepreneurship could be a means of getting rid of this unemployment deficit. However, the government needs to check previous policies and make new ones that would make entrepreneurship attractive to young people. More so, soft loan should be made available to entrepreneurs and young people that would like to become entrepreneurs. Platform that would help entrepreneurs develop themselves like workshop, seminars and conferences should be made affordable for entrepreneurs. This study therefore concluded that, entrepreneurship is a solution to unemployment challenges in developing countries. 
DOI: 10.21522/TIJMG.2015.SE.19.01.Art009

ISSN: $2520-310 \mathrm{X}$

Figures and tables

Table 1a: Frequency Distribution of Respondents by Sex

\begin{tabular}{|l|l|l|l|l|l|}
\hline \multirow{2}{*}{} & & & & & Cumulative \\
Valid & Male & 218 & 67.5 & 67.5 & 67.5 \\
\cline { 2 - 6 } & Fequency & Percent & Valid Percent & Percent \\
\cline { 2 - 6 } & Total & 323 & 32.5 & 32.5 & 100.0 \\
\hline
\end{tabular}

Table 1b. Frequency distribution of respondents by educational attainment educational attainment

\begin{tabular}{|l|l|l|l|l|l|}
\hline \multirow{3}{*}{ Valid } & & Frequency & Percent & Valid Percent & $\begin{array}{l}\text { Cumulativ } \\
\text { e Percent }\end{array}$ \\
\cline { 2 - 6 } & Primary Education & 0 & 0.0 & 0.0 & 0.0 \\
\cline { 2 - 6 } & $\begin{array}{l}\text { Secondary } \\
\text { Education }\end{array}$ & 181 & 56.0 & 56.0 & 56.0 \\
\cline { 2 - 6 } & Tertiary Education & 78 & 24.0 & 24.0 & 80.0 \\
\cline { 2 - 6 } & Post graduates & 64 & 20.0 & 20.0 & 100.0 \\
\hline Total & 323 & 100.0 & 100.0 & \\
\hline
\end{tabular}

Table 1c. Frequency distribution of respondents by religion religion

\begin{tabular}{|l|l|l|l|l|l|}
\hline & & Frequency & Percent & Valid Percent & $\begin{array}{l}\text { Cumulativ } \\
\text { e Percent }\end{array}$ \\
\hline \multirow{3}{*}{ Valid } & Christianity & 255 & 78.9 & 78.9 & 78.9 \\
\cline { 2 - 6 } & Islamic & 68 & 21.1 & 21.1 & 100.0 \\
\cline { 2 - 6 } & Others & 0 & 0.0 & 0.0 & 100.0 \\
\hline \multicolumn{2}{|l|}{ Total } & 323 & 100.0 & 100.0 & \\
\hline
\end{tabular}

Table 2. Descriptive statistics showing factors militating against adoption of entrepreneurship in nigeria

\begin{tabular}{|l|l|l|l|l|l|}
\hline & $\mathrm{N}$ & Minimum & Maximum & Mean & Std. Deviation \\
\hline Governmental Policies & 323 & 1 & 5 & 4.19 & .415 \\
\hline $\begin{array}{l}\text { Availability and sources of } \\
\text { fund }\end{array}$ & 323 & 1 & 5 & 3.80 & .610 \\
\hline $\begin{array}{l}\text { Inadequate knowledge of } \\
\text { areas to explore }\end{array}$ & 323 & 1 & 5 & 3.30 & .971 \\
\hline Family background & 323 & 1 & 5 & 3.62 & .898 \\
\hline Individual career choice & 323 & 1 & 5 & 2.88 & 1.294 \\
\hline Valid N (listwise) & 323 & & & & \\
\hline
\end{tabular}

Decision rule: item is accepted at mean $=$ or $>$ than 3.0 and rejected at mean less than 3.0 
Table 3. Descriptive statistics showing the influence of entrepreneurship on unemployment challenges

\begin{tabular}{|l|l|l|l|l|l|}
\hline $\begin{array}{l}\text { Entrepreneurship may help } \\
\text { to improve individual } \\
\text { financial capacity }\end{array}$ & N & Minimum & Maximum & Mean & Std. Deviation \\
\hline $\begin{array}{l}\text { The standard of living of } \\
\text { the people can be improved } \\
\text { through adoption of } \\
\text { entrepreneurship as career }\end{array}$ & 323 & 1 & 5 & 3.35 & .713 \\
\hline $\begin{array}{l}\text { Unemployment will } \\
\text { gradually fade out at } \\
\text { increasing } \\
\text { entrepreneurship uptake }\end{array}$ & 323 & 1 & 5 & 3.19 & .415 \\
\hline $\begin{array}{l}\text { Entrepreneurship uptake } \\
\text { could turn youths away } \\
\text { from all forms of violence }\end{array}$ & 323 & 1 & 5 & 3.20 & .610 \\
\hline $\begin{array}{l}\text { Entrepreneurship uptake } \\
\text { will help reduce the } \\
\text { poverty level in the country }\end{array}$ & 323 & 1 & 5 & 3.30 & .971 \\
\hline \begin{tabular}{l} 
Valid N (listwise) \\
\hline
\end{tabular} & 323 & & 5 & 3.62 & .898 \\
\hline
\end{tabular}

Decision rule: item is accepted at mean= or $>$ than 3.0. and rejected at mean less than 3.0

Table 4. Descriptive Statistics showing What could be done to make young people adopt entrepreneurship in Nigeria

\begin{tabular}{|l|l|l|l|l|l|}
\hline & & Minimum & Maximum & Mean & Std. Deviation \\
\hline $\begin{array}{l}\text { The entrepreneurship studies } \\
\text { in tertiary institutions should } \\
\text { be reviewed and should be } \\
\text { practical oriented }\end{array}$ & 323 & 1 & 5 & 3.88 & .394 \\
\hline $\begin{array}{l}\text { Government at all level should } \\
\text { organize entrepreneurship } \\
\text { workshop and seminar in place } \\
\text { of worship, communities and } \\
\text { other areas of concentration to } \\
\text { include other youths }\end{array}$ & 323 & 1 & 5 & 3.35 & .713 \\
\hline $\begin{array}{l}\text { Government should endavour } \\
\text { to make soft loan available for } \\
\text { entrepreneurs to enable them } \\
\text { improve their productivity }\end{array}$ & 323 & 1 & 3 & 3.19 & .415 \\
\hline $\begin{array}{l}\text { Entrepreneurs should be } \\
\text { assisted financially to attend } \\
\text { international conferences to } \\
\text { help }\end{array}$ & 323 & 1 & 4 & 3.20 & .610 \\
\hline
\end{tabular}


DOI: 10.21522/TIJMG.2015.SE.19.01.Art009

ISSN: 2520-310X

\begin{tabular}{|l|l|l|l|l|l|}
\hline $\begin{array}{l}\text { All media platforms should be } \\
\text { engaged in the campaign for } \\
\text { adoption of entrepreneurship } \\
\text { using ever Nigeria languages }\end{array}$ & 323 & 1 & 4 & 3.30 & .971 \\
\hline Valid N (listwise) & 323 & & & & \\
\hline
\end{tabular}

Decision rule: item is accepted at mean $=$ or $>$ than 3.0. and rejected at mean less than 3.0.

\section{References}

[1]. Arenius, P. and Minniti, M. (2003), "Women in Entrepreneurship". The Entrepreneurial Advantage of Nations: First Annual Global Entrepreneurship Symposium, United Nations Publications, April.

[2]. Audretsch, D. and R. Thurik (2004), A model of the entrepreneurial economy, International Journal of Entrepreneurship Education 2(2), 143-166.

[3]. Bokhari, A. (2013). Entrepreneurship as a Solution to Youth Unemployment in the Kingdom of Saudi Arabia. American Journal of Scientific Research. Issue 87, pp.120-134. Available at American Journal of Scientific Research.

[4]. Brown, C. (2000), "Entrepreneurial education Teaching Guide", Kansas City. M O: Kauffman Centre for Entrepreneurial Leadership Clearing House on Entrepreneurship Education. pp. 1-13.

[5]. Ediagbonya, K. (2013). Perceptions of Business Education Students on the Relevance of Entrepreneurship Education at the Colleges of Education in Edo State. Unpublished Project. Journal of Business Administration and Education 46.

[6]. Okojie J.A. (2008). 'Policy Framework and Strategy for Entrepreneurship Development for Nigerian Universities'. A Paper Presented at the National Sensitization Workshop on Entrepreneurship Development in Nigerian Universities Organized by National Universities Commission, Abuja, 21 May.

[7]. Oluwole T (2003). A Synopsis of Disciplines and Careers. Akure, Ondo State Nigeria. Orteeyz Ltd.

[8]. Osibanjo O (2006). 'Concept of Entrepreneurship. `A Paper Presented at the Workshop on Entrepreneurship and Innovation for 200 - Level students in University of Ibadan, Jan. 18.

[9]. Yakubu MA (2000). Guidance and Counselling. Beginner's Guide. Jos, Nigeria. Deka Enterprises (Nigeria). 